Olja Arsenijević ${ }^{1}$

Dragan Trivan ${ }^{2}$

Milan Milošević ${ }^{3}$

Union University - Nikola Tesla,

Faculty of Business Studies and Law
SCIENTIFIC REVIEW ARTICLE doi:10.5937/ekonomika1604105A

Received: August 08, 2016

Accepted: November 03, 2016

\title{
STORYTELLING AS A MODERN TOOL OF CONSTRUCTION OF INFORMATION SECURITY CORPORATE CULTURE
}

\begin{abstract}
The aim of this paper is to highlight the importance of organizational storytelling as a modern instrument for the construction of information-security corporate culture. The paper defines the term "'storytelling”, formulates the basic tasks of using it, as well as the storytelling application areas in the organization. As a special emphasis on corporate culture of information security, the paper discusses the technology for creating information-security corporate culture, as well as transmission, dissemination and preservation of knowledge and information in an organization, with the use of storytelling. The paper, based on analysis of literature and practice, emphasizes the advantages of storytelling in the formation of learning and information-security organization culture.
\end{abstract}

Keywords: storytelling, management, organizational culture, knowledge management, information security.

JEL classification: M140.

\section{СТОРИТЕЛИНГ КАО САВРЕМЕНИ ИНСТРУМЕНТ ИЗГРАДЫЕ ИНФОРМАЦИОНО-БЕЗБЕДНОСНЕ КОРПОРАТИВНЕ КУЛТУРЕ}

\begin{abstract}
Апстракт
Циљ рада је да укаже на значај организачионог сторителинга као савременог инструмента за изградну информаџионо-безбедносне корпоративне културе. У раду се дефинише појам “сторителинг”, формулишу се основни задаци коришћења, као и области примене сторителинга у организацији. Како је посебан нагласак на корпоративној култури информаичоне безбедности, у раду се разматра технологија креирана информационо-безбедносне корпоративне културе, те преношења, иирења и чувања знања и информачија у организацији уз коришћење сторителинга. У раду се, на основу анализе литературе и
\end{abstract}

\footnotetext{
${ }^{1}$ olja.arsenijevic@fpsp.edu.rs

2dtrivan@gmail.com

${ }^{3}$ milan.milosevic@fpsp.edu.rs
} 
праксе, наглашавају предности примене сторителинга у формирању учеће и информационо-безбедносне организационе културе.

Кључне речи: сторителинг, управљање, организациона култура, управљање знањем, информациона безбедност.

\section{Introduction}

Each organization in the process of its life cycle builds its narrative, meets with problems and solve them more or less successfully, entering new situations, and, in cooperation with the external environment, transforms its internal environment. The narrative can be realistic, to some extent exaggerated, or else - completely fabricated. Whatever, it may influence the organization, its members and cooperation with business partners, positively or negatively. It may also affect the fulfillment of their goals or be an obstacle. Sharing experiences through a narrative appears in various professions as a great way for knowledge exchange and determination. Researches suggest that sharing experiences through narrative mode builds trust and promotes norms, transfers tacit knowledge, enables learning, and creates emotional connections. Narratives can be a powerful way of presenting and conveying the complex and multidimensional ideas. Well-designed and well-told stories can transmit the information and emotions, explicit and tacit, as well as core and context.

Skill of narrative management, maintaining and developing a positive one, correct and timely transposition to those who need it, neutralizing the negative elements, and occasionally creating a new one - these are the tasks of modern managers who aspire to raise the effectiveness of social relations in the organization, by using the storytelling method.

\section{Storytelling - concept and essence}

Storytelling is the use of narrative skills that is the art of narration, in areas that were not originally considered as a narrow field of application, at least not until now. Pointing to the universal of the narrative and its seductiveness, and the need for its wider application in areas such as marketing, management, politics, military, Salmon in "Storytelling" reveals that the possibilities of storytelling in modern times do not retain only to their aesthetic plan, but it can be interpreted as utilitarian category. (Salmon, 2010) This, then, arises from the growing need to actually transform the whole current propaganda operation. Salmon in his paper asks: "Has a narrative skill, which explains the experience of mankind since its inception, in the storytelling era, became a national instrument of lies and control of thoughts? Behind the brands and television series, but also in the shadow of winning the election campaigns from Bush to Sarkozy, and military operations in Iraq or elsewhere, worthy storytelling technicians are hidden. Empire seized narrative." (Salmon, 2010) The basic thesis of storytelling says: at all times tell a story! Why? Our mindset is accustomed to the narrative organization, conceptual operation with the help of images that is trying to line up in a certain experiential model, or pattern. We, therefore, live in and with graphics and images, with notions that we process narratively by giving them a meaning, shaping them so that they can fit into the horizon of expectations, creating our own world (make impossible possible), but also our 
own life. Such feedback, narrative disposition of man on the one hand, and the subsequent processing of the seen, experienced but returned (now as a final content), placed in a story that has its own exposition, plot, development, outcome, protagonists, antagonists, punch line ...) on the other hand requires that our relationship to the surrounding world is formed precisely on the basis of material derived from the given possibilities and resources.

Salmon in his work about the predominance of the former storytelling forms of communication practices moves the focus into the sphere of management, asking himself again and again what actually causes the advantage of one over another paradigm, and where the roots of the evolutionary, historic, progressive changes are. Historically, the origins of this phenomenon were found in England, the industry leading power in the mid-nineteenth century, with the advent of the manufacturing method of production. Rearranging different forms of labor force in the same space and the subjugation to a hierarchical organization, strict supervision and the deafening noise of the original industrial machinery, necessarily lead to proper etiquette at the level of interpersonal communication among members of the workforce. Workers' speech was perceived as "chatter" or "gossip" at best, and at worst it was interpreted as a silent resistance or subversion. No surprise then that the strike was initially meant as a valve for such suspension. However, how long this situation could give desirable results? With changing the mode of production, sophisticated technologies and overall social change at all levels, "organizational" or "systematic silence" relationship form stopped functioning. Moreover, it has become counterproductive. A series of financial failures, breakdowns caused by poor internal staff coordination, forced top managers to completely re-examine the reasons and the causes of this phenomenon. After a long and detailed analysis, a complete turnaround was made. For management gurus only one solution became possible: silence should not be imposed to the employees. (Salmon, 2010) On the contrary, it should be expelled by an opposite order - to talk and confess. In the corps of newly permitted "sins", almost imperatively, gossip takes its place, as a form of narrative that inevitably carries information. Benefits of liberated tabooed behavior in the workplace were immediately registered by the apparent "contribution to the maintenance of the notification system of rules and values, transferring the tradition and history of the company. (Fog et al. 2010) New knowledge about the benefits of this approach says about the power of narrative, which "lies in the complex experiences as a combination of senses, mind, emotions and imagination.” (Armstrong, 1992)

Consequently, the new company becomes a creative workshop, a kind of narrative organization, where the narrative is heard, cultivated, regulated and, of course, controlled. If you take a closer look, a lot of things around us are the narrative, the activities of a company as well. One would not say at first glance, but isn't the reports about the visit to the client, business interviews and curriculum vitae (autobiographical narration) actually forms of storytelling? "In this way, storytelling management is nothing more than an attempt to control the streaming of the story." (Salmon, 2010; Gerasimenko, 2006; Prusak et all. 2004)

With the rise of storytelling and its all the more sensational successes, you can see the reciprocal decrease in dull, boring, rational argumentation, almost obligatorily presented in an even more boring power-point medium, with tiring and discouraging effect on employees. What is that telling us, and at this level of analyses, what conclusion we can get? The mesmerizing power of the story targets the irrational layer of personality, dependent of archetypal sediment and performance, by native mythic patterns inherent to the human race as a whole set of structural features which make the narrative or story so effective. Of course, in storytelling management semiotics is not the only goal and purpose - it always has utilitarian properties, but in a more serious approach to the 
storytelling phenomenon, it is hard to bypass it, at least as a direct and indirect assistant in the aim to enrich and improve one area. Therefore, we can rightfully claim that the success of storytelling here, in fact, was enabled by a sort of "regression of the company's world (consciousness) to the universe of stories and fiction.” Narrative won ineffectiveness. (Salmon, 2010; Hovichkova, 2012, Fog et all. 2010; Aaker \& Joachimsthaler, 2009.)

Storytelling is a way of transmitting information and knowledge, as well as inducing desired behaviors and actions by using the instructive story. Also, storytelling can be defined as the art of fascinating and suggestive narration. (Simmons, 2006.)

Organizational storytelling is a management tool used for understanding, interpretation, and dissemination of values, norms, rules and principles of organizational culture through the use of corporate stories, myths and legends. These can be stories about the work of management in the past, on cooperation in the organization or on certain events. Storytelling enables targeted impact on employees, both those who are already working in the organization, and those new employees, through corporate stories, myths and legends. (Reami, 2002.)

Leader as a teacher helps people in organization to develop system understanding expand their capacities in order to understand complexity, make vision clear and improve

mutual mental models.(Micić, 2015)

Storytelling is also the informal method of personnel training. The first attempts of creating and using stories in business were different in form. Employees were encouraged to write down the things they learned, make catalogs of knowledge, as well as today's "yellow pages", but with a list of employees and the knowledge that they have, maps of informal networks of experts in the organization were created.

While the actions were different, their base was the same - increasing the effectiveness of the creation, interpretation and acceptance of ideas. (Hovichkova, 2012.)

The narrative contains four required elements without which there is no effect on the audience: the message, the conflict, the heroes, the story.

Organizational myths and legends play a very important role in the organizational culture. (Janićijević, 2013) Myths are narratives that are partly based on real facts, a partly fictional. They are directed to the desired future and have to indicate the employee's perspective. Corporate legends do not have to basically rely on organizational events, on the contrary, and if completely fabricated, they are intended to manipulate public opinion, or the opinion of a certain collective. Using corporate myths and legends for managing organizational culture is considered to be a part of internal PR.

Heroes of corporate narrative can be: founders, who led the company to success with their enthusiasm, managers of the company, who have made successes with individual projects, employees who are able to deal with unusual problems, and the like.

Storytelling method was first used in the international company Armstrong International, by David Armstrong, general manager of the company. The idea of managing the personnel with the help of narratives was used also at Birmingham University. Professor Kevin Thompson, when creating concepts for attracting staff, concluded that the narrative is one of the best methods of motivation.

\section{Storytelling as an element of corporate memory}

Storytelling uses the oral method of transmitting information and knowledge, as the most effective. This method allows direct communication, with all its advantages. Increasingly, it is 
also used in written form on paper or electronic media. The basis for the preservation and use of knowledge at various holders in the company is the structure of corporate memory model.

Corporate memory is the ability of the organization to keep, collect and produce informal and formal organizational skills, which are composed of experience and tradition necessary for the development of competencies of the organization.

Using knowledge of corporate memory provides affirmation of cooperation among organizational units, effective personnel management and work with clients (Novichkova, 2012). If the knowledge exist in two forms - invisible (human experience and practice) and formalized (documents and records), corporate memory determines cultural and technological process of collection, storage, use, evaluation and application of knowledge.

The functioning of the corporate memory presupposes the existence of a structural entity that collects and processes the knowledge in the organization, facilitating their spread through administrative barriers and integrates them into operational business processes (Novichkova, 2012.) In addition, it facilitates the exchange of knowledge, so knowledge becomes available to all organizational units, and the like.

The goals of formation of corporate memory are: preclusion of loss of knowledge with the departure of certain professionals, using experience gained while working on projects, drawing lessons from the past, the preclusion of future errors (this is especially important for corporate security of organizations); the use of knowledge maps of the organization to build corporate strategy, accelerating the circulation of information and knowledge and increasing the effectiveness of communication, which is also one of the preconditions for the construction of corporate security; improving of personnel training system, and analysis and application of the experience of other companies in operation.

The main advantage that a company acquires, by using the model of corporate memory, is the ability to concentrate knowledge in a unique complex corpus, fast access to knowledge, reducing the time to acquire some knowledge, reducing the risk of the human factor, which is one of the most common causes of compromising corporate security.

\section{Information-security corporate culture}

Culture can be defined as the characteristic beliefs and behaviors that exist in an organization. It is a collection of formal and informal behaviors that the organization has adopted as its way of doing business (Guptara, 1994). Corporate culture determines the behavior of its employees and affects the formation of acceptable behavior within the organization (Beach, 1993).

Information-security culture is an integral part of the corporate culture and it also has to do with the behavior of employees (Schlienger \& Teufel, 2003). The ways in which employees perform their duties are based on collective values, norms and knowledge and have a decisive influence on the success of the entire organization. Information-security culture occupies a very small part of the research and there is not a single definition, or attitude on what should be a corporate culture that will lead to the appropriate method of management of information security culture...

Corporate culture has a very strong impact on data security (Chang \& Lin, 2007). It is important to note that corporate culture should reflect a positive attitude towards 
information security throughout the organization and to be consistent with good practice of information security culture.

Information-security culture is based on improving employee awareness of the importance of data and how to deal with it, as well as the adoption of desirable behavior models in the context of corporate culture (Da Veiga \& Eloff, 2010:198).

Some authors have found that only paying attention to the corporate culture of security is not enough to understand all the factors that affect the security of information and culture (Helokunnas \& Kuusisto, 2003).

Dhillon stresses that the organizations in which the culture of information security is not prevailing, will be in a serious problem with maintaining the integrity and protection of technical systems organizations (Dhillon, 1997). He also believes that informationsecurity culture should be an integral part of the corporate culture, which, after all, was confirmed by the conclusions reached by other authors - information security culture is a set of beliefs and respect for certain values that are manifested in actions and behavior of employees in data protection organization (Andress \& Fonseca, 2000; Breidenbach, 2000; Von Solms, 2000, Ramachandran, Srinivasan, Tim, 2008.).

Literature defines three types of mutual relations of corporate culture and information security culture:

1. Information security culture is separated from the corporate culture (members do not participate or take a very little part in the implementation of security in organizations, and their awareness of the importance of security is very low; activities that are related to information security employees is performed only by IT department) (Albrechtsen, 2007);

2. Information security culture is a subculture of corporate culture (members of the organization take care of information security only within their organizational units, occasionally trained for mandatory training, each subculture associates its needs with responsibilities and work tasks of certain professional groups, such as accounting, etc.) (an Ramachandran, Srinivasan, Tim,.2008)

3. Information-security culture is integrated into the corporate culture (corporate security is a concern of all employees and is implemented in a holistic manner; in this type of culture, data protection is a part of the business routine). (Thomson, von Solms, Louw, 2006)

\section{Storytelling as an instrument of construction of information security culture}

In order for the information-security culture to become an integral part of corporate culture, all employees must become aware of its importance. With specific focus, organizations can quickly move to the highest level of information security.

The human factor is the cause of more than $75 \%$ of security incidents. The vast majority of these incidents occurred accidentally because employees were not aware of the consequences of their (usually harmless) actions. Therefore, it is important that everyone understands what are the likely threats to the property and the entire enterprise business and how to properly behave to reduce the risks inherent in these threats. In addition, 
each employee must be fully aware of its role in protecting the system when managing people, information and assets. Other organizations, electronically communicated, as well as our external service providers should also be fully aware of their role in terms of security, information and funds. Most important of all is that the senior management of the enterprise must understand threats and risks, implement security measures and fulfill its obligations under the adopted corporate safety programs. Explicit actions of the management in this area will demonstrate to all staff, partners and service providers that the company is committed to protecting its people, information and resources.

One of the instruments to build a corporate culture, in which information and safety culture will be an integral part, is storytelling.

The main tasks of storytelling in the construction of this type of corporate culture are related to:

1. The movement of established tradition in the organization and consolidating previously accepted corporate ideology. Storytelling enables building links between the past, present and future. Use of narrative helps to learn more about corporate values and principles by which it works, so these can be followed. Employee loyalty increases with a sense of belonging to the collective and complete identification with the mission, vision and goals of the organization. It also reduces the need for financial motivation.

We have already mentioned that the availability of invisible property, which accounts for about $80 \%$ of organizational knowledge, is only possible in the process of interpersonal relationships. The basic mechanism for building the most valuable knowledge and their application is personal communication among employees in the sphere of influence of the community through which a corporate narrative circulates.

2. Introduction of a new corporate ideology. Use of narrative enables new employees to quickly understand the corporate ideology, norms of behavior and work. To learn more about the organization are often used codes of conduct, corporate regulations etc., but storytelling helps new employees to enter more deeply into the system and find the right role for himself in the corporate environment.

3. Training of employees by administering examples of safe behavior and work. Thanks to the narratives of successful or unsuccessful experience, there is an exchange of skills and experience among employees, reducing the amount of repetitive mistakes, leveling of the stress of newly employed in case of mistake. Invisible knowledge, which is found in every segment of the professional activity and is not recorded in any instruction or knowledge base of organizations, is best transferred through informal channels.

4. Employee motivation by personal narrative. Every organization today can share narratives about its wise founders, decisive leaders and loyal employees, protection of business secrets, data, intellectual capital, know-how... It would be useful to keep all information about security managers who have successfully counteract the loss of data, dealing with information-security risks, etc. These narratives allow employees to experience the corporate culture focused on the promotion of new ideas, initiative, self-education, raising the level of competence and information security, as well as the intellectual potential of employees, which raises the level of accountability 
of employees and reduces the fluctuation.

5. Storytelling expands the arsenal of resources of personnel motivation and reinforces the reputation of leaders, resulting in creating of the form of imitation.

6. Control of employees' attitudes toward managers' omissions and problematic situations with which the organization meets periodically. Corporate narratives are particularly effective in moments of crisis.

7. Improving the effectiveness of communications at all levels. In order to raise awareness of information security throughout the organization it is necessary to implement a communication program that will ensure that employees understand the need for implementation of best practices for information security, and to inform them about their roles and responsibilities in the development of an efficient system of information security.

Companies that use storytelling and support corporate myths, manage to form an effective information-security culture and substantially increase the level of employee motivation (Smirnova \& Voskresenskaja, 2009).

\section{Conclusion}

For the information security in organizations, the attention is paid mostly to the physical and technical measures, and very little on the social and cultural factors that influence it.

We believe that neglecting of this segment is largely the cause of the problems in modern organizations.

The application of storytelling enables:

- creating a corporate culture of information security, knowledge, including corporate traditions, norms, values, ideology, rules, leadership, interaction in achieving the strategic objectives of the organization;

- management of motivation and training of employees;

- $\quad$ raising of the level of effectiveness of business processes, creation, storage and use of information and knowledge;

- $\quad$ raising the level of effectiveness of communication in the organization and reducing of the level of formalization;

- building a positive image of the organization in the outer and inner environment - storytelling is the most important instrument in relations with the public;

- controlling the problematic, crisis periods in the functioning of the organization, lowering resistance to change, raising the level of effectiveness of organizational changes.

Keeping knowledge in corporate memory enables pooling of resources into a single point for all employees, structures knowledge in accordance with its importance, customizes knowledge, enables analyzing and forecasts risk. In addition, the preservation of knowledge provides avoiding past mistakes. At the same time, the experience of mutual relations with clients, employees and stakeholders can be helpful in the future. It can be played both in the form of formalized, as well as unformalized knowledge of employees, in part or in full, in corporate narratives, myths and legends. 


\section{References}

Aaker, D. \& Joachimsthaler, E. (2009). Brand Leadership. Building Assets in an Information Economy. The Free Press. New York.

Albrechsten, E. (2007). A Qualitative Study of Users View on Information Security. Computer and Security 26(4), 276-289.

Andress, M., Fonseca, N. (2000) Manage People to Protect Data. Infoworld 22(46), 48.

Armstrong, D. G. (1992). Managing by Storying Around: A New Method of Leadership. Doubleday. New York.

Beach, I.R. (1993) Making the right decision. Organizational culture, vision and planning. Eaglewood Cliffs. Prentice Hall. New Jersey.

Breidenbach, S. (2000). How Secure Are You? Information Week 800:71-8.

Chang, S.E. \& Lin, C. (2007). Exploring organisational culture for information security management. Industrial Management and Data Systems 107(3), 438-458.

Da Veiga, A. \& Eloff. J.H.P. (2010). A framework and assessment instrument for information security culture. Computer and Security 29, 196-207.

Dhillon, G. (1997). Managing Information System Security, Houndmills. Basingstoke. Macmillan Press LTD. Hampshire.

Fog, K., Budtz, C., Munch, P. Blanchette, S. (2010). Storytelling: Branding in Practice. Springer, Berlin.

Gerasimenko, O. (2006). Storytelling - effektivnyy variant neformalnogo obucheniya, Trainings. ru. Retrieved jun 2016. from http://www.trainings.ru/library/ articles/?id=6330.

Guptara, P. (1994). Lessons of experience - learning from others. D. Lock (ed.). Handbook of Quality Management. Gower. Aldershot.

Helokunnas, T. \& Kuusisto, R. (2003). Information Security Culture in a Value Net. IEEE International Engineering Management Conference.

Janićijević, N. (2013). Organizaciona kultura. CID Ekonomski fakultet. Beograd.

Micić, R. (2015) Leadership Role in Creatin Phases of Knowledge Management Processes, Ekonomika, Vol. 61, october-december 2015. No. 4, p. 47-56, Društvo ekonomista „Ekonomika“ Niš.

Novichkova, A. V. (2010). Korporatsii znaniya. Vestnik Inzhekona 2 (29). SanktPeterburgskiy inzhenerno-ekonomicheskiy universitet. Sankt Peterburg.

Novichkova, A. V. (2012). Foremirovanie modeli korporativnoy pamyati v sisteme upravljeniya znaniyami innovatsionnykh organizatsiy: Dissertatsiya kandidata ekonomicheskikh nauk. GUU. Moskva.

Prusak, L., Groh, K., Denning, S., Brown, J.S. (2004). Storytelling in Organizations. Elsevier.

Ramachandran, S., Srinivasan, V. R., Tim, G. (2008). Information Security Cultures of Four Professions: A Comparative Study. Proceedings of the $41^{\text {st }}$ Hawaii International Conference on System Sciences. Hawaii. 
Reami, T. (2002). Imparting knowledge throuhg storytelling. KM World July/August 2002, V. 11, Issue 7.

Salmon, K. (2010). Storytelling ili pričam ti priču. Klio. Beograd.

Schlienger, T. \& Teufel, S. (2003). Analyzing information security culture: increased trust by an appropriate information security culture. TrustBus 03 workshop in conjunction with the $14^{\text {th }}$ International Vonference on Database and Expert Systems Applications (DEXA 2003).

Simmons, A. (2006). The Story Factor: Inspiration, Influence, and Persuasion Through the Art of Storytelling. Basic Books. Cambridge.

Smirnova, V., Voskresenskaya, Y. (2009). Knowledge culture as key factor of knowledge management. Global Business and Technology Association Eleventh Annual Conference "Business Strategies and Technological Innovations for Sustainable Development: Creating Global Prosperity for Humanity". Prague. Chech Republic.

Thomson, K., von Solms, R., Louw, L. (2006). Cultivating an Organizational Information Security. Culture, Computer, Fraud and Security 2006(10), $7-11$.

Von Solms, B. (2000). Information Security - The Third Wave? Computer and Security 19(7), 615-620. 